\title{
Persepsi Wajib Pajak Mengenai Penggelapan Pajak, Keadilan Sistem Perpajakan Dan Tax Amnesty Pada Kepatuhan Perpajakan
}

\author{
Ni Ketut Lely Aryani Merkusiwati ${ }^{1}$ \\ Fakultas Ekonomi dan Bisnis \\ Universitas Udayana, Indonesia
}

\author{
I Gusti Ngurah Agung Suaryana ${ }^{2}$ \\ Fakultas Ekonomi dan Bisnis \\ Universitas Udayana, Indonesia
}

\section{Surel: lelyaryanimer@unud.ac.id}

\section{ABSTRAK}

Pajak merupakan sumber utama penerimaan negara. Wajib pajak orang Pribadi (WP) memiliki kontribusi dalam pemasukan pajak yang tercatat masih rendah di Provinsi Bali. Data WP di Kantor Pelayanan Pajak (KPP) Pratama Badung Utara menjelaskan terdapat keterlambatan dalam menyampaikan SPT tahunan walaupun setiap tahunnya sudah mulai berkurang. Kondisi ini menandakan adanya sikap tidak patuh WP. Penelitian ini bertujuan untuk menganalisis pengaruh persepsi penggelapan pajak, keadilan pajak, Tax Amnesty terhadap kepatuhan perpajakan. Sampel pada penelitian ditentukan dengan teknik simple random sampling. Jumlah sampel penelitian yakni 100 wajib pajak. Analisis SEM PLS. Hasil penelitian menunjukkan semakin tinggi persepsi penggelapan pajak maka semakin besar ketidakpatuhan perpajakannya. Persepsi keadilan sistem perpajakan tidak berpengaruh terhadap kepatuhan perpajakan. Semakin banyak wajib pajak melakukan Tax Amnesty maka semakin kecil tingkat kepatuhan awal pada sistem perpajakan.

Kata Kunci: Penggelapan Pajak; KeadilanSistem Perpajakan; Tax Amnesty; Kepatuhan Perpajakan

\section{Taxpayer Perceptions Regarding Tax Embezzlement, Fairness of the Taxation System and Tax Amnesty on Tax Compliance}

\begin{abstract}
Taxes are the main source of state revenue. Individual taxpayers (WP) have a low contribution to tax revenue in Bali Province. Taxpayer dataat the North Badung Pratama Tax Service Office (KPP) explains that there is a delay in submitting the annual SPT, althoughevery year it has begun to decrease. This condition indicates a non-compliant attitude of the WP. This study aims to analyze the effect of perceptions of tax evasion, tax justice, Tax Amnesty on tax compliance. The sample in the study was determined by simple random sampling technique. The number of research samples is 100 taxpayers. PLS SEM analysis. The results showed that the higher the perception of tax evasion, the greater the tax non-compliance. The perception of fairness of the taxation system has no effect on tax compliance. The more taxpayers carry out Tax Amnesty, the smaller the initial level of compliance with the tax system.

Keywords: $\quad$ Tax evasion; Fairness of the Taxation System; Tax Amnesty; Tax Compliance.
\end{abstract}

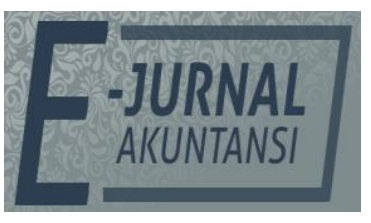

e-ISSN 2302-8556

Vol. 31 No. 12

Denpasar, Desember 2021

Hal. 3207-3220

DOI:

10,24843/EJA.2021.v31.i12.p13

PENGUTIPAN:

Merkusiwati, N. K. L. A. \&

Suaryana, I. G. N. A. (2021).

Persepsi Wajib Pajak

Mengenai Penggelapan

Pajak, Keadilan Sistem

Perpajakan Dan Tax Amnesty

Pada Kepatuhan Perpajakan.

E-Jurnal Akuntansi, 31(12), 3207-3220

\section{RIWAYAT ARTIKEL:}

Artikel Masuk:

20 September 2021

Artikel Diterima:

16 Desember 2021

Artikel dapat diakses: https:/ / ojs.unud.ac.id/index.php/Akuntansi/index 


\section{PENDAHULUAN}

Undang-Undang Dasar tahun 1945 pada pasal 23A telah mengatur tentang aturan perpajakan yang sifatnya memaksa. Pajak memiliki pengaruh besar dalam pembangunan nasional karena pajak menyumbang rata-rata lebih dari 70 persen dari keseluruhan pendapatan negara. Indonesia termasuk negara yang memiliki tingkat penerimaan pajak yang rendah. Dirjen Pajak menjelaskan bahwa saat ini rasio penerimaan pajak (tax ratio) Indonesia saat ini berada di angka 11,5 persen. Angka tax ratio Indonesia masih jauh dibawah negara-negara ASEAN lain seperti Malaysia yang memiliki tax ratio 15 persen, Filipina yang memiliki tax ratio 14,5 persen dan Singapura yang memiliki tax ratio 13,6 persen. Rasio penerimaan pajak Indonesia bahkan masih jauh berada di baw ah standar negara-negara Organization on Economic Cooperation and Development (OECD) yang umumnya memiliki tax ratio sebesar 14\% (Kemenkeu, 2019).

Kementerian Keuangan mencatat realisasi penerimaan pajak Agustus 2019 mencapai Rp801,02 triliun atau 50,78 persen dari target APBN 2019 yang sebesar Rp 1.577,56 triliun (Kemenkeu, 2019). Kepatuhan formal WP (WP) hingga Juli 2019 sebesar 12,3 juta atau 67,2 persen dari jumlah WP yang wajib menyampaikan SPT sebanyak 18,3 juta. Data otoritas pajak menunjukkan dari jenis WPnya, WP karyawan termasuk yang paling patuh di antara WP lainnya dengan rasio kepatuhan pada angka 73,6 persen, sedangkan kelompok korporasi hanya 57,28 persen dan WP orang kaya atau nonkaryawan masih di bawah 50 persen atau 42,75 persen. Kepatuhan formal WP hingga Juli 2019 baru sebesar 12,3 juta atau 67,2 persen dari jumlah WP yang wajib menyampaikan SPT sebanyak 18,3 juta (Suwikyo, 2019). Faktor yang mempengaruhi penerimaan pajak suatu negara diantaranya adalah tingkat kepatuhan WP di negara tersebut (Chau \& Leung, 2009).Berdasarkan informasi tersebut dapat ditarik kesimpulan kepatuhan WP belum optimal.

Kepala Kanwil DJP Bali Goro Ekanto menyatakan bahwa kontribusi WP orang pribadi di Bali kurang lebih hanya 1 persen dari total penerimaan pajak. Kontribusi WP orang pribadi di Bali masih rendah. Umumnya untuk negara menuju negara modern penerimaan pajak dari WP orang pribadi setidaknya imbang atau lebih besar dari penerimaan pajak badan usaha (Balipost, 2019). Data penerimaan pajak di Kantor pelayanan Pajak (KPP) Pratama Badung Utara tidak memenuhi target penerimaan kemungkinan karena kurang patuhnya WP dalam melaporakan pajaknya. Tabel 1 menjelaskan rasio penerimaan pajak KPP Pratama Badung Utara tahun 2016-2018 belum mencapai 100 Persen.

Tabel 1. Rasio Penerimaan Pajak di KPP Pratama Badung Utara

\begin{tabular}{lcccc}
\hline Tahun & Target & Realisasi & $\begin{array}{c}\text { Rasio } \\
\text { Penerimaan* }\end{array}$ \\
\hline 2016 & $\operatorname{Rp} 619.919 .595 .000,00$ & $\operatorname{Rp~} 491.782 .831 .240,00$ & $79 \%$ \\
2017 & $\operatorname{Rp~} 586.131 .479 .000,00$ & $\operatorname{Rp~} 540,969.168 .114,00$ & $92 \%$ \\
2018 & $\operatorname{Rp~} 660,034.517 .000,00$ & $\operatorname{Rp~} 628.143 .773 .394,00$ & $95 \%$ \\
\hline
\end{tabular}

${ }^{*}$ Rasio Penerimaan $=($ Realisasi $:$ Target $) \times 100 \%$

Sumber: KPP Pratama Badung Utara, 2019

KPP Pratama Badung Utara juga mencatat penyampaian SPT tahunan. Berdasarkan data Tabel 2 Kantor pelayanan pajak (KPP) Badung Utara dijelaskan jumlah WP orang pribadi yang terus meningkat sejak 2016-2018 dari 47.004 orang 
sampai 55.627 orang tahun 2018. Data Tabel 2 menjelaskan peningkatan jumlah WP yang meningkat tidak diikuti dengan peningkatan penyampaian SPT tahuan yang tepat waktu. Tercatat WP yang tidak melaporkan SPT tahunan meningkat dari tahun 2016-2018 yaitu dari 33,695 persen menjadi 43,283 persen ditahun 2018. Berdasarkan data tersebut maka terlihat tingkat ketidakpatuhan perpajakan meningkat pada KPP Badung Utara tahun 2016-2018.

\section{Tabel 2. Penyampaian SPT Tahunan WP di KPP Pratama Badung Utara}

\begin{tabular}{|c|c|c|c|c|c|c|c|}
\hline $\begin{array}{l}\text { Tahun } \\
\text { Penyam } \\
\text { paian } \\
\text { SPT }\end{array}$ & $\begin{array}{c}\text { Jumlah } \\
\text { WP } \\
\text { Efektif }\end{array}$ & \multicolumn{2}{|c|}{$\begin{array}{l}\text { Tepat Waktu } \\
\text { Penyampaian }\end{array}$} & \multicolumn{2}{|c|}{$\begin{array}{c}\text { Terlambat } \\
\text { Menyampaikan } \\
\text { SPT }\end{array}$} & \multicolumn{2}{|c|}{$\begin{array}{c}\text { Tidak } \\
\text { Menyampaikan } \\
\text { SPT }\end{array}$} \\
\hline & $\begin{array}{l}\text { Jumlah } \\
\text { (Orang) }\end{array}$ & $\begin{array}{l}\text { Jumlah } \\
\text { (Orang) }\end{array}$ & & $\begin{array}{l}\text { Jumlah } \\
\text { (Orang) }\end{array}$ & & $\begin{array}{l}\text { Jumlah } \\
\text { (Orang) }\end{array}$ & \\
\hline 2016 & 47.004 & 22.404 & $47,664 \%$ & 4.810 & $10,233 \%$ & 15.838 & $33,695 \%$ \\
\hline 2017 & 50,638 & 24.235 & $47,859 \%$ & 2.487 & $4,911 \%$ & 19.321 & $38,155 \%$ \\
\hline 2018 & 55.627 & 25.932 & $46,618 \%$ & 1.190 & $2,139 \%$ & 24.077 & $43,283 \%$ \\
\hline
\end{tabular}

Sumber: KPP Pratama Badung Utara (2019).

Kepatuhan wajib pajak (Doran, 2009) bertujuan untuk memenuhi kewajiban perpajakanya perlu ditingkatkan untuk menciptakan target pajak yang diinginkan. Kepatuhan WP menunjukkan suatu norma yang dimiliki WP (Lederman, 2003), karena kepatuhan pajak merupakan norma, maka pelanggaran terhadap kepatuhan pajak akan dikenakan sanksi. Menurut (Riyanto et al, 2020) untuk meningkatkan kepatuhan pajak, WP tidak hanya diberikan sanksi tetapi juga perlu adanya kesadaran yang timbul dari diri WP. Selain itu, sikap dan perilaku pelaku atau petugas pajak menjadi salah satu contoh dan perhatian bagi WP dalam bersikap terhadap kepatuhan pajak. Kasus yang dilakukan oleh petugas pajak mempengaruhi kepercayaan WP dalam membayar pajak (Riyanto, Wujarso, Saprudin, 2020). Kasus penggelapan pajak menjadi salah satu indikator penting yang menyebabkan adanya masalah kepatuhan pajak. Kasus penggelapan pajak menyebabkan WP kehilangan kepercayaan terhadap petugas pajak. Persepsi Penggelapan pajak mengakibatkan krisis kepercayaan WP kepada institusi dan dapat berdampak pada kepatuhan perpajakannya (McGee et al., 2006).

Faktor lain yang mempengaruhi kepatuhan akan perpajakan yaitu keadilan sistem perpajakan. Keadilan memiliki peran yang sangat sensitif bagi WP. Menurut (Andarini, 2010) keadilan pajak terjadi ketika WP mendapatkan manfaat yang sebanding dengan apa yang mereka bayarkan (Berutu \& Harto, 2013). Keadilan pajak bagi WP akan timbul ketika WP merasakan manfaat dari beban pajak yang telah WP bayarkan. Ketika WP merasakan adanya ketidakadilan dalam pajak maka niat untuk membayar pajak akan terpengaruh (Retyowati, 2016). Semakin adil sistem pajak maka semakin tinggi keinginan WP dalam membayar pajak. Keadilan pajak mempengaruhi kepatuhan pajak dan sikap WP dalam membayar pajak. Beberapa hal telah dilakukan guna meningkatkan keadilan dalam sistem perpajakan. Sistem perpajakan telah direformasi dalam hal sistem perpajakan dan tata cara perpajakan yang mengutamakan keadilan. Keadilan sistem pajak akan meningkatkan kepercayaan seseorang terhadap sistem perpajakan. Kondisi ini tentu akan meningkatkan keinginan wajib pajak dalam membayarkan pajaknya. 
Beban pajak yang adil seharusnya disesuaikan dengan kemampuan WP dan masyarakat dalam membayar pajak (Berutu \& Harto, 2013). Perbaikan sistem perpajakan akan meningkatkan kepatuhan pajak. Sistem pajak yang adil mampu meningkatkan kepatuhan WP sistem pajak yang mengedepankan keadilan akan meningkatkan rasa percaya WP kepada institusi. Hal ini mendorong WP patuh terhadap pajak. Penelitian (Berutu \& Harto, 2013) dan (Retyowati, 2016) menyatakan keadilan sistem perpajakan memiliki peran penting pada ketidakpatuhan pajak. Upaya lain perintah untuk meningkatkan kepatuhan WP adalah memberikan pengampunan pajak atau Tax Amnesty. Pengampunan pajak ini adalah salah satu upaya pemerintah untuk mengatasi kekurangan penerimaan pajak dan menilai tingkat kepatuhan WP. Pengampunan pajak belum maksimal meningkatkan penerimaan negara tetapi cukup membuat WP mau melaporkan asset yang dimiliki yang belum dicatat oleh negara yang belum kena pajak juga sehingga dapat menambah penerimaan negara. Penggelapan pajak, keadilan dalam sistem pajak dan pengampunan pajak merupakan variabel yang berperan penting dalam kepatuhan perpajakan.

Ketidakpatuhan seseorang terhadap pajak dapat dipengaruhi oleh orang lain (Cahyonowati, 2011). Proses pengamatan individu terhadap perilaku yang muncul secara eksternal maupun internal dapat mempengaruhi kepatuhan pajak individu lainnya. Ketika WP yang taat akan pajak mengamati perilaku atau indikasi kecrangan yang dilakukan oleh petugas maka kondisi ini akan mempengaruhi sikap WP dalam membayarkan pajak. Tindakan petugas pajak sangat mempengaruhi kepatuhan WP. Apabila WP melihat adanya indikasi kecurangan maka hal ini akan mempengaruhi sikap dan pemikiran WP untuk melakukan penggelapan pajak. Penelitian (Dhanayanti \& Suardana, 2017) dan (Surahman \& Putra, 2018)) menemukan bahwa adanya hubungan positif dan signifikan antara penggelapan pajak terhadap kepatuhan pajak. Hal ini menunjukkan bahwa penyeludupan pajak berpengaruh terhadap kepatuhan WP dalam membayarkan pajak. Semakin tinggi persepsi penggelapan pajak maka semakin tinggi ketidakpatuhan WP pada sistem perpajakan. Maka hipotesis yang diajukan adalah sebagai berikut.

$\mathrm{H}_{1}$ : Persepsi penggelapan pajak berpengaruh positif terhadap kepatuhan perpajakan.

Menurut (Otekunrin et al., 2021; Susmiantu dan Kusmuriyanto., 2014), penghindaran pajak dapat terjadi ketika WP merasakan ketidakadilan pada sistem pajak. Keadilan pajak memiliki peran yang sangat penting dalam menentukan sikap WP dalam membayar pajak. Penelitiannya (Retyowati, 2016) menemukan bahwa keadilan sistem perpajakan memiliki pengaruh signifikan terhadap ketidakpatuhan pajak. Keadilan sistem pajak meningkatkan kepatuhan pajak seseorang dan ketaatan dalam membayar pajak. Semakin tinggi persepsi keadilan perpajakan yang dilakukan oleh fiskus maka semakin patuh WP terhadap sistem perpajakan, sehingga hipotesis penelitian ini sebagai berikut.

$\mathrm{H}_{2}$ : Persepsi keadilan sistem perpajakan berpengaruh positif terhadap kepatuhan perpajakan.

Pengaruh Tax Amnesty terhadap kepatuhan perpajakan dikuatkan Theory of Planned Behavior. Keyakinan normative merupakan sikap seseorang yang cenderung dipengaruhi oleh lingkungan sekitarnya (Ajzen, 1991). Sikap individu 
yang melakukan pengamatan terhadap lingkungan sekitar dapat mempengaruhi kemaunya untuk mengikuti program Tax Amnesty. WP yang awalnya tidak patuh dalam sistem perpajakan dan akhirnya mengikuti pengampunan pajak menunjukan bahwa WP ingin melaksanakan kepatuhannya kepada negara. Slippery Slope Framework berpendapat bahwa kepercayaan pembayar pajak pada pemerintah dan persepsi WP tentang kekuasaan pemerintah menjelaskan sejauh mana kepatuhan pajak WP. Tax Amnesty memberikan bukti bahwa WP secara sukarela melakukan kepatuhan perpajakan yang awalnya tidak patuh, hasil pada studi di Asia (Inasius et al., 2020). Berdasarkan teori dan kajian empiris maka semakin meningkat WP yang mengikuti Tax Amnesty maka semakin rendah tingkat kepatuhan awal WP kepada sistem perpajakan yang ada. Hipotesis penelitian yang ingin dibuktikan adalah:

$\mathrm{H}_{3}$ : Tax Amnesty berpengaruh negatif terhadap tingkat kepatuhan sistem perpajakan.

\section{METODE PENELITIAN}

Penelitian ini dilakukan di Kantor Pelayanan Pajak Pratama Badung Utara. Obyek dalam penelitian ini adalah Wajib Pajak Orang Pribadi (WPOP) yang melakukan kegiatan perpajakan di Kantor Pelayanan Pajak Pratama Badung Utara. Populasi penelitian yakni semua Wajib Pajak Orang Pribadi (WPOP) yang ada di Kantor Pelayanan Pajak Pratama Badung Utara yang mempunyai NPWPsebanyak 55.627 wajib pajak orang pribadi. Sampel penelitian dipilih secara random sampling. Penentuan jumlah sampel dengan metode slovin sehingga jumlah responden 100 responden.

Metode dokumentasi digunakan untuk mengumpulkan data terkait dengan tingkat kepatuhan WP dalam membayarkan pajak. Penelitian ini menggunakan metode angket atau kuisioner dalam mengumpulkan data. Memberikan beberapa pertanyaan yang tertulis kepada responden untuk dijawab merupakan bentuk pengumpulan data dengan menggunakan kuisioner. Kuisioner akan diberikan kepada WPorang pribadi yang telah terdaftar pada KPP Pratama Badung Utara menggunakan google form yang sebarkan kepada wajib pajak. Penelitian menggunakan teknik pengumpulan data non partisipan. Metode ini dilakukan dengan mengumpulkan data dengan tidak terlibat secara langsung. Metode ini dilakukan dengan mencatat, memperhatikan, mengutip dan mengumpulkan data dari dokumen.

Variabel independen penelitian yakni persepsi penggelapan pajak, keadilan sistem perpajakan dan pengampunan pajak (Tax Amnesty). Indikator guna mengukur presepsi WP tentang penggelapan pajak terdiri dari 4 (empat) berdasarkan konsep (Surahman \& Putra, 2018) dan (Surono \& Hidayat, 2014). Adapun empat indikator yang digunakan untuk mengukur persepsi penggelapan pajak terkait dengan penerpan tarif pajak dan kerjasama fiskus dan wajib pajak, hubungan hukum dengan tindakan penggelapan pajak, integritas aparatur perpajakan, dan biaya tinggi.

Keadilan sistem pajak pada penelitian ini diukur dengan tiga indikator (Berutu \& Harto, 2013). Adapun ketiga indikator yang digunakan dalam mengukur keadilan sistem pajak yakni berkaitan dengan sistem pajak penghasilan, pajak penghasilan 
yang dibebankan serta besarnya pajak yang harus dibayarkan. Skala likert 5 digunakan untuk mengukur variabel dalam penelitian.

Pengampunan pajak atau Tax Amnesty diukur dengan 6 indikator pengukuran yaitu surat penyataan harta yang mendapatkan pengampunan, kelengkapan surat pengampunan harta, pelaporan pengampunan harta secara sukarela, penyataan melunasi seluruh tunggakan, pernyataan membayar tebusan, dan perasan senang adanya program pengampunan pajak (Kartini, 2018). Pengukuran masing-masing variabel Tax Amnesty dilakukan dengan menggunakan kuesioner skala likert dengan skala yang digunakan yaitu skala 1-5. Analisis data penelitian ini terdiri atas analisis statistik deskriptif dan analisis statistik induktif. Analisis statistik deskriptif bertujuan untuk memperoleh gambaran mengenai karakteristik dari variabel penelitian. Analisis statistik induktif yang dipergunakan dalam penelitian ini adalah SEM PLS karena penelitian ini menggunakan variabel laten dan beberapa instrumen penelitian.

\section{HASIL DAN PEMBAHASAN}

Data Tabel 2 yang diperoleh dari KPP menjelaskan alasan menggunakan KPP Pratama Badung Utara sebagai objek penelitian. KPP Pratama Badung Utara karena terdapat peningkatan jumlah WP periode 2016-2018 tetapi tidak diikuti dengan peningkatan penyampaian SPT tahuan yang tepat waktu. Tercatat WP yang tidak melaporkan SPT tahunan meningkat dari tahun 2016-2018 yaitu dari 33,695 persen menjadi 43,283 persen di tahun 2018.

Berdasarkan metode penentuan sampel acak dengan rumus slovin maka diperoleh 100 responden penelitian. Profil dari 100 responden dalam penelitian dinyatakan dalam karakteristik demografi responden. Responden pada penelitian yang berjumlah 100 responden telah mengisi kuisioner penelitian. Jenis kelamin serta umur merupakan karakteristik responden.

\section{Tabel 3. Demografi Responden}

\begin{tabular}{|c|c|c|c|c|}
\hline $\mathrm{No}$ & Keterangan & & Jumlah & Persentase \\
\hline \multirow[t]{6}{*}{1} & Umur & & & \\
\hline & $21-30$ & tahun & 21 & $21 \%$ \\
\hline & $31-40$ & tahun & 32 & $32 \%$ \\
\hline & $41-50$ & tahun & 35 & $35 \%$ \\
\hline & $51-60$ & tahun & 12 & $12 \%$ \\
\hline & & & 100 & $100,00 \%$ \\
\hline \multirow[t]{4}{*}{2} & Jenis kelamin & & & \\
\hline & Laki-laki & & 78 & $78 \%$ \\
\hline & Perempuan & & 22 & $22 \%$ \\
\hline & & & 100 & $100,00 \%$ \\
\hline
\end{tabular}

Sumber: Data Penelitian, 2021

Sebaran umur responden paling banyak pada rentang umur 41 tahun sampai dengan 50 tahun sebanyak 35 orang atau 35 persen, diikuti dengan rentang umur 31 sampai dengan 40 tahun sebanyak 32 orang atau 32 persen. Jenis kelamin responden sebagian besar laki-laki 78 persen, sedangkan responden perempuan sebanyak 22 persen. Berdasarkan hasil jawaban persepsi responden terhadap penggelapan pajak yang terjadi karena ada celah dari fiskus, sanksi hukum yang ringan untuk kasus penggelapan, kemudahan menyuap fiskus, dan adanya kasus 
korupsi. Berdasarkan butir pernyataan tersebut jawaban responden selanjutnya setuju bahwa WP besar selalu berusaha menghindar pajak karena biaya untuk menyuap petugas pajak masih lebih kecil dibandingkan dengan penghematan pajak sebesar 51 persen dan sangat setuju 48 persen atau rata-rata skor 3,47. Butir pernyataan selanjutnya persepsi penggelapan pajak dilakukan jika wajib pajak yang memiliki penghasilan sama tetapi tidak melakukan kewajiban membayar pajaknya juga yang sama besar, sebanyak 52 persen menjawab setuju, dan 45 persen sangat setuju (SS), dengan rata-rata jawaban 3,42. Persepsi responden menilai sistem keadilan perpajakan adil sehingga responden menjadi patuh setuju sebanyak 62 persen, sangat setuju 37 persen dan tidak setuju 1 persen dengan ratarata jawaban 3,36. Sebagian besar responden patuh membayar pajak karena adanya sistem keadilan yaitu tarif, sanksi dan alokasi yang jelas penggunaan pajak untuk masyarakat sehingga manfaat pembayaran pajak dapat dirasakan oleh semua pihak. Hasil jawaban responden yang tidak setuju sebanyak 1-4 persen.

Berdasarkan jawaban responden atas pernyataan mengenai Tax Amnesty (TA) sebagian besar menjawab setuju dan sangat setuju. Hanya sebagian kecil yang menjawab tidak setuju. Sebanyak 99 persen responden telah mengikuti TA secara sukarela dan merasa sebelum tidak menyampaikan harta yang dimiliki pada SPT tahunan. Sebagian besar responden membayar dan melunasi uang tebusan sebagai konsekuensi pengampunan pajak. Sebagai besar jawaban responden dengan adanya program TA untuk meningkatkan kepatuhan perpajakan.

Berdasarkan jawaban responden atas pernyataan mengenai Tax Amnesty (TA) sebagian besar menjawab setuju dan sangat setuju. Hanya sebagian kecil yang menjawab tidak setuju. Sebanyak 99 persen responden telah mengikuti TA secara sukarela dan merasa sebelum tidak menyampaikan harta yang dimiliki pada SPT tahunan. Sebagian besar responden membayar dan melunasi uang tebusan sebagai konsekuensi pengampunan pajak. Sebagai besar jawaban responden dengan adanya program TA untuk meningkatkan kepatuhan perpajakan.

Kepatuhan perpajakan termasuk pembayaran pajak sukarela sesuai dengan peraturan perundangan perpajakan. Pembayaran pajak dilakukan karena takut hukuman dan diaudit sesuai dengan undang-undang perpajakan sehingga menjadi patuh (Cahyonowati, 2011; Picur dan Riahi-Belkaoui, 2006). Hasil jawaban dari responden tentang persepsi responden terhadap kepatuhan perpajakan. Jawaban responden atas empat pernyataan variabel kepatuhan perpajakan terkonsentrasi pada jawaban setuju dan sangat setuju. Namun demikian, masih ada tanggapan tidak setuju atas pernyataan kondisi kepatuhan perpajakan. Sebanyak 99 persen responden memiliki NPWP dan mendaftarkan secara sukarela. Hasil jawaban responden terhadap kepatuhan perpajakan menjelaskan pada umumnya responden berusaha untuk patuh terhadap perundang-undangan. Responden berusaha melaporkan dan membayar tepat waktu. Alasan responden untuk patuh sebagian besar dijelaskan untuk menghindari sanksi dan denda serta pemeriksaan.

Analisis model pengukuran terdiri atas pengujian validitas dan reliabilitas instrumen. Uji validitas digunakan untuk mengukur sah atau tidaknya suatu instrumen penelitian dalam hal ini kuesioner. Uji validitas menilai kemampuan 
instrumen penelitian dalam mengukur apa yang seharusnya diukur. Suatu kuesioner dinyatakan valid a pabila item pertanyaan yang terdapat pada kuesioner mampu menangkap aspek yang akan diukur. Uji validitas meliputi uji validitas konstruk, yaitu menilai tingkat kesesuaian satu pengukuran dengan teori-teori yang digunakan untuk mendefinisikan konstruk (Chin \& Todd, 1995).

Tabel 4. Hasil pengujian validitas konvergen dengan Average Variance Extracted (AVE)

\begin{tabular}{|c|c|c|c|c|}
\hline & $\begin{array}{c}\text { Penggelapan } \\
\text { Pajak }\end{array}$ & $\begin{array}{c}\text { Keadilan } \\
\text { Sistem } \\
\text { Perpajakan }\end{array}$ & $\begin{array}{c}\text { Tax } \\
\text { Amnesty }\end{array}$ & Kepatuhan Perpajakan \\
\hline $\mathrm{X} 1.1$ & 0,785 & & & \\
\hline $\mathrm{X} 1.2$ & 0,869 & & & \\
\hline $\mathrm{X} 1.3$ & 0,864 & & & \\
\hline X1.4 & 0,890 & & & \\
\hline $\mathrm{X} 1.5$ & 0,932 & & & \\
\hline X1.6 & 0,882 & & & \\
\hline $\mathrm{X} 1.7$ & 0,836 & & & \\
\hline $\mathrm{X} 2.1$ & & 0,721 & & \\
\hline $\mathrm{X} 2.2$ & & 0,783 & & \\
\hline $\mathrm{X} 2.3$ & & 0,773 & & \\
\hline $\mathrm{X} 2.4$ & & 0,830 & & \\
\hline $\mathrm{X} 2.5$ & & 0,827 & & \\
\hline $\mathrm{X} 2.6$ & & 0,799 & & \\
\hline X3.1 & & & 0,881 & \\
\hline $\mathrm{X} 3.2$ & & & 0,878 & \\
\hline X3.3 & & & 0,910 & \\
\hline X3.4 & & & 0,933 & \\
\hline X3.5 & & & 0,867 & \\
\hline X3.6 & & & 0,749 & \\
\hline Y1 & & & & 0,869 \\
\hline Y2 & & & & 0,867 \\
\hline Y3 & & & & 0,893 \\
\hline Y4 & & & & 0,925 \\
\hline Y5 & & & & 0,871 \\
\hline Y6 & & & & 0,811 \\
\hline
\end{tabular}

Sumber: Data Penelitian, 2021

Pengujian validitas konstruk meliputi validitas konvergen dan validitas diskriminan. Validitas konvergen mengukur korelasi antar pengukur dari konstruk. Validitas konvergen diukur dengan loading faktor (korelasi antara skor komponen dengan skor kontruk). PLS mengukur validitas konvergen dengan skor outer loading dan average variance extracted (AVE). Item pengukur dinyatakan valid apabila skor outer loading harus lebih besar daripada 0,5 dan average variance extracted (AVE) lebih besar daripada 0,5 dan signifikan p-value $<0,05$ serta 
memiliki kesamaan koefisien/kovari (Chin \& Todd, 1995). Hasil pengujian validitas konvergen disajikan pada Tabel 4.

Tabel4. yang menjelaskan outer loading, yaitu korelasi antara skor masing-masing komponen dengan skor konstruk. Nilai outer loading seluruhnya lebih besar daripada 0,5 sehingga dapat disimpulkan seluruh komponen valid secara convergent.

Uji reliabilitas adalah istilah yang digunakan untuk menunjukan sejauh mana suatu hasil pengukuran relatif konsisten apabila pengukuran dilakukan berulang kali atau diulang kembali. Uji reliabilitas mengukur konsistensi alat ukur atau instrumen penelitian (Chin \& Todd,1995). Penelitian menggunakan compasite reliability dan cronbach's Alpha yang merupakan pengukuran reliability antar blok indikator dari variabel yang membentuk model penelitian. Compasite reliability dan cronbach's Alpha dikatakan baik jika nilainya diatas 0,70, Tabel 5 menunjukan hasil uji reliabilitas pada penelitian ini.

Tabel 5. Hasil pengujian Cronbach's Alpha, rho_A, Composite Reliabilty dan Average Variance Extracted (AVE)

\begin{tabular}{lcccc}
\hline & $\begin{array}{c}\text { Cronbach's } \\
\text { Alpha }\end{array}$ & rho_A & $\begin{array}{c}\text { Composite } \\
\text { Reliability }\end{array}$ & $\begin{array}{c}\text { Average } \\
\text { Variance } \\
\text { Extracted } \\
\text { (AVE) }\end{array}$ \\
\hline Penggelapan pajak $\left(\mathrm{X}_{1}\right)$ & 0,944 & 0,948 & 0,954 & 0,751 \\
Keadilan perpajakan $\left(\mathrm{X}_{2}\right)$ & 0,898 & 0,979 & 0,908 & 0,624 \\
Tax Amnesty $\left(\mathrm{X}_{3}\right)$ & 0,936 & 0,944 & 0,950 & 0,760 \\
Kepatuhan perpajakan $(\mathrm{Y})$ & 0,937 & 0,939 & 0,950 & 0,763 \\
Sumber: data diolah, 2021 & & & & \\
\hline
\end{tabular}

Sumber: Data Penelitian, 2021

PLS menguji validitas diskriminasi dengan Cross loading. Rule of thumb yang digunakan adalah skor cross loading dalam satu variabel lebih besar daripada 0,7 (Chin \& Todd, 1995). Hasil pengujian validitas diskriminan disajikan pada Tabel 6.

Tabel 6 menyajikan skor cross loading dari masing-masing indikator variabel penelitian. Seluruh indikator memiliki nilai cross loading lebih besar dari 0,7 pada tiap-tiap variabel penelitian. Hasil evaluasi model pengukuran/measurement model/outer model yang didasarkan pada kriteria covergent validity, discriminant validity, composite reliability dan cronbach's Alpha, menunjukan bahwa telah memenuhi kriteria pengujian validitas dan reliabilitas, maka masing-masing indikator dapat dinyatakan valid dan reliabel, sehingga dapat dilanjutkan ke proses berikutnya.

Model struktural dalam PLS dievaluasi dengan menggunakan koefisien determinasi (R2) untuk konstruk dependen, nilai koefisienjalur (path) atau nilai statistik t untuk setiapjalur. Nilai R2 mengukur tingkat variasi perubahan variabel terhadap variabel dependen. Semakin tinggi nilai R2, berarti semakin baik model prediksi dari model penelitian yang ajukan. Validitas model diukur menggunakan koefisien determinasi total ( $\mathrm{R} 2$ total). Koefisien determinasi total ( $\mathrm{R} 2$ total) adalah koefisien determinasi keseluruhan variabel endogen. Nilai Koefisien determinasi akan dijelaskan pada Tabel 7. 
Tabel 6. Hasil Pengujian Validitas Diskriminan dengan Cross Loading

\begin{tabular}{|c|c|c|c|c|}
\hline & $\begin{array}{c}\text { Penggelapan } \\
\text { pajak }\end{array}$ & $\begin{array}{c}\text { Keadilan } \\
\text { Sistem } \\
\text { Perpajakan }\end{array}$ & $\begin{array}{c}\text { Tax } \\
\text { Amnesty }\end{array}$ & Kepatuhan Perpajakan \\
\hline $\mathrm{X} 1.1$ & 0,785 & $-0,018$ & 0,752 & 0,673 \\
\hline $\mathrm{X} 1.2$ & 0,869 & $-0,009$ & 0,689 & 0,833 \\
\hline$X 1.3$ & 0,864 & $-0,003$ & 0,690 & 0,832 \\
\hline $\mathrm{X} 1.4$ & 0,890 & $-0,040$ & 0,654 & 0,860 \\
\hline X1.5 & 0,932 & $-0,108$ & 0,686 & 0,889 \\
\hline $\mathrm{X} 1.6$ & 0,882 & $-0,091$ & 0,633 & 0,838 \\
\hline $\mathrm{X} 1.7$ & 0,836 & $-0,134$ & 0,567 & 0,784 \\
\hline$X 2.1$ & $-0,072$ & 0,721 & 0,104 & $-0,172$ \\
\hline$X 2.2$ & $-0,046$ & 0,783 & 0,055 & $-0,086$ \\
\hline $\mathrm{X} 2.3$ & $-0,009$ & 0,773 & 0,152 & $-0,010$ \\
\hline$X 2.4$ & $-0,049$ & 0,830 & 0,079 & $-0,083$ \\
\hline$X 2.5$ & $-0,012$ & 0,827 & 0,179 & $-0,069$ \\
\hline $\mathrm{X} 2.6$ & $-0,064$ & 0,799 & 0,075 & $-0,069$ \\
\hline X3.1 & 0,657 & 0,145 & 0,881 & 0,579 \\
\hline $\mathrm{X} 3.2$ & 0,640 & 0,085 & 0,878 & 0,566 \\
\hline X3.3 & 0,706 & 0,133 & 0,910 & 0,639 \\
\hline X3.4 & 0,727 & 0,064 & 0,933 & 0,645 \\
\hline X3.5 & 0,707 & 0,126 & 0,867 & 0,626 \\
\hline X3.6 & 0,552 & 0,115 & 0,749 & 0,455 \\
\hline Y1 & 0,813 & $-0,068$ & 0,626 & 0,869 \\
\hline Y2 & 0,809 & $-0,061$ & 0,627 & 0,867 \\
\hline Y3 & 0,837 & $-0,096$ & 0,592 & 0,893 \\
\hline Y4 & 0,879 & $-0,168$ & 0,624 & 0,925 \\
\hline Y5 & 0,828 & $-0,151$ & 0,569 & 0,871 \\
\hline Y6 & 0,782 & $-0,191$ & 0,504 & 0,811 \\
\hline
\end{tabular}

Sumber: Data Penelitian, 2021

Tabel 7. Koefisien Determinasi

\begin{tabular}{lcc}
\hline Variabel Endogen & R Square & R Square Adjusted \\
\hline Kepatuhan perpajakan & 0,902 & 0,899 \\
\hline
\end{tabular}

Sumber: Data Penelitian, 2021

Nilai koefisien determinasi total ( $\mathrm{R} 2$ total) sebesar 0,902 artinya informasi yang terkandung dalam data 90,21\% dapat dijelaskan oleh model analisis hubungan antar variabel seperti yang tergambar pada Gambar 1, sedangkan sisanya 9,79\% oleh faktor lainnya yang tidak diikut sertakan dalam penelitian ini.

Nilai koefisien jalur atau linner model menunjukan tingkat signifikansi dalam pengujian hipotesis. Hasil analisis koefisien jalur disajikan pada tabel 8 dan Gambar 1. Tabel 8 menyajikan jalur yang menjelaskan pengaruh variabel eksogen/endogen pada variabel endogen, koefisien jalur, statistik $t$, P value, dan kesimpulan hasil pengujian hipotesis penelitian (hipotesis ditolak atau diterima). 
Tabel 8. Hasil Hipotesis

\begin{tabular}{|c|c|c|c|c|}
\hline Jalur & $\begin{array}{l}\text { Koefisien } \\
\text { Jalur }\end{array}$ & T Statistics & P Values & Keterangan \\
\hline $\begin{array}{lll}\text { Penggelapan pajak } & -> \\
\text { kepatuhan perpajakan } & \end{array}$ & 1.009 & 26.978 & 0,000 & H1 di terima \\
\hline $\begin{array}{l}\text { Keadilan sistem perpajakan } \\
\text {-> kepatuhan perpajakan }\end{array}$ & $-0,061$ & 0,856 & 0,392 & H2 di tolak \\
\hline $\begin{array}{l}\text { Tax Amnesty } \rightarrow \text { kepatuhan } \\
\text { perpajakan }\end{array}$ & $-0,090$ & 2.035 & 0,042 & H3 di terima \\
\hline
\end{tabular}

Sumber: Data Penelitian, 2021

Gambar 1 menyajikan diagram jalur. Diagram jalur menjelaskan kekuatan hubungan antar variabel yang dinyatakan dengan koefisien jalur

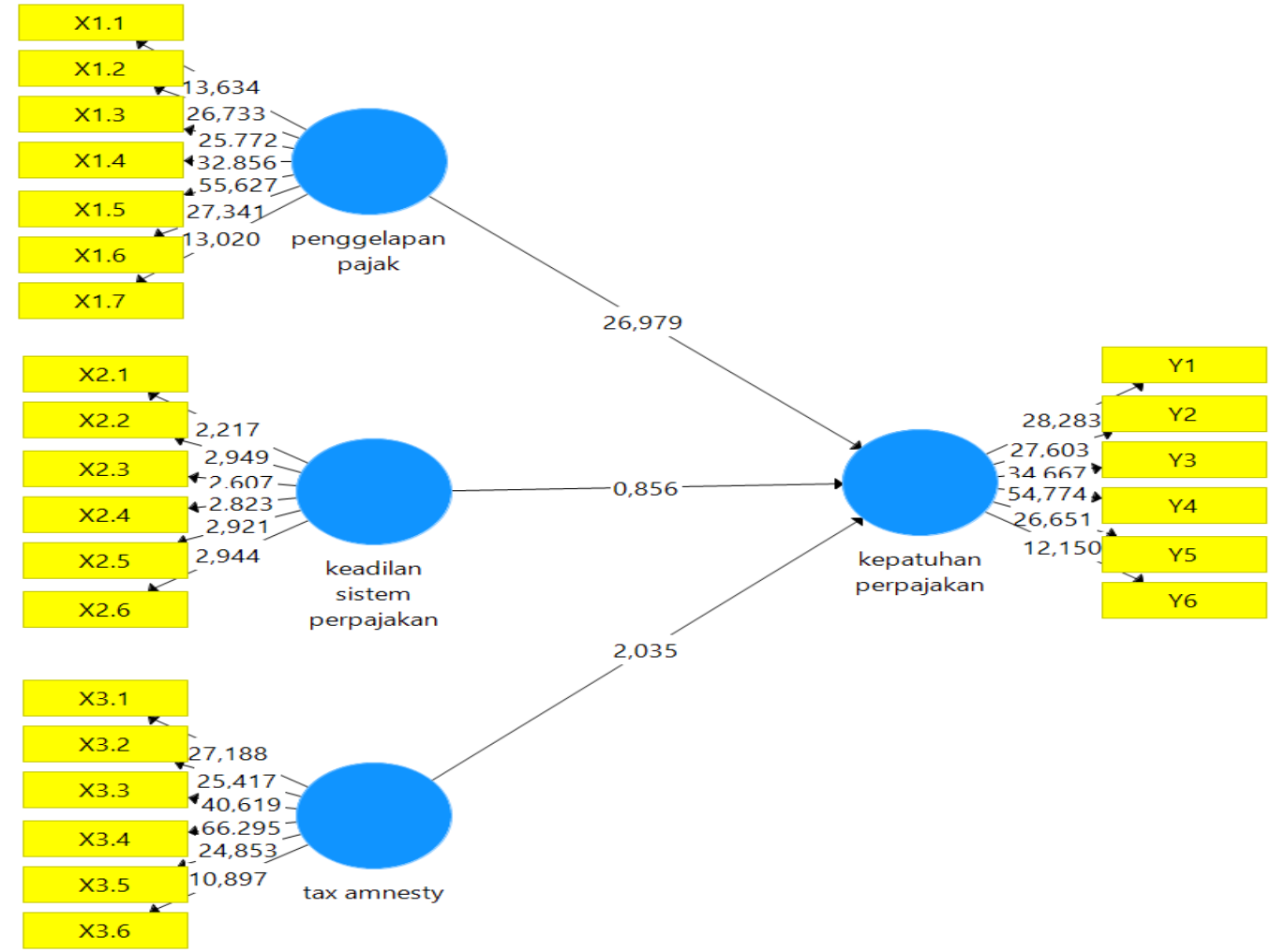

Gambar 1. Diagram t-Statistik

Sumber: Data Penelitian, 2021

Hasil pengujian menunjukkan koefisien jalur sebesar 1,0099, nilai statistik t sebesar 26,976 dan $p$ value sebesar 0,0000, Nilai $p$ value lebih kecil daripada $a=$ 0,05 , sehingga $\mathrm{H}_{1}$ diterima. Hipotesis penelitian kedua $\left(\mathrm{H}_{2}\right)$ yaitu persepsi keadilan sistem perpajakan berpengaruh terhadap kepatuhan pajak tidak diterima. Hasil pengujian menghasilkan nilai koefisien jalur sebesar -0,0611, nilai statistik $\mathrm{t}$ sebesar 0,8564 , dan nilai $\mathrm{p}$ value sebesar 0,3922 . Nilai $\mathrm{p}$ value yang dihasilkan lebih besar daripada a $=0,05$, sehingga $\mathrm{H}_{2}$ ditolak. Hipotesis penelitian ketiga $\left(\mathrm{H}_{3}\right)$ yaitu Kemauan mengikuti Tax Amnesty berpengaruh negatif terhadap kepatuhan perpajakan. Hasil pengujian menghasilkan nilai koefisien jalur sebesar -0,0900, nilai statistik t sebesar 2.0352, dan nilai $p$ value sebesar 0,0424 . Nilai $p$ value yang dihasilkan lebih kecil daripada $\mathrm{a}=0,05$, sehingga $\mathrm{H}_{3}$ diterima. 
Hasil pengujian hipotesis pertama penelitian $\left(\mathrm{H}_{1}\right)$ membuktikan persepsi penggelapan pajak berpengaruh positif terhadap kepatuhan perpajakan. Persepsi penggelapan sistem perpajakan menurut hasil responden 63 persen setuju dan 36 persen sangat setuju pada jawaban instrumen no 1 pengelapan pajak terjadi jika ada celah yang berikan oleh fiskus pada saat wajib pajak melakukan pembayaran. Hasil penelitian ini mendukung hasil penelitian yang menemukan bahwa persepsi penggelapan pajak berpengaruh terhadap kepatuhan perpajakan adalah penelitian (Picur \& Riahi-Belkaoui, 2006), (Surahman \& Putra, 2018), (Surono \& Hidayat, 2014).

Hasil penelitian menjelaskan persepsi keadilan yang dirasakan wajib pajak mulai dari keadilan tarif, keadilan sistem, keadilan penggunaan dan manfaat pajak tidak mempengaruhi kepatuhan wajib pajak pada sistem perpajakan. Hal ini membuktikan bahwa pesepsi wajib pajak tentang keadilan perpajakan tidak serta merta menyebabkan wajib pajak untuk menjalankan kepatuhan perpajakan. Hasil jawaban responden hanya 4 persen menyatakan bahwa tidaksetujuadanya timbal balik pemerintah dari pajak yang sudah dialokasikan secara adil. Berdasarkan hasil jawaban responden pada instrumen keadilan perpajakan nomor 3 sebanyak 57 persen setuju dan 40 persen sangat setuju kepatuhan WP pada ketentuan perpajakan untuk menghindari kemungkinan sanksi kantor pajak. Hasil penelitian tidak sejalan dengan penelitian yang dilakukan (Retyowati, 2016) mengemukakan bahwa kepatuhan pajak dan keadilan sistem perpajakan memiliki pengaruh signifikan. Hasil penelitian yang sejalan dengan penelitian oleh (Basri et al, 2014).

Hasil pengujian hipotesis ketiga penelitian $\left(\mathrm{H}_{3}\right)$ diterima Penelitian ini membuktikan bahwa semakin besar wajib pajak melakukan Tax Amnesty maka semakin kecil tingkat kepatuhan awal perpajakannya. Hasil penelitian mendukung teori persepsi. Teori persepsi menyatakan terkait dengan perilaku seseorang yang dipengaruhi oleh adanya lingkungan sekitarnya (Ajzen, 1991). Perilaku seperti ini disebut juga dengan perilaku normative. Sikap seseorang dalam mengamati lingkungan sekitar maupun perilaku seseorang merupakan salah satu bentuk dari teori atribusi (Inasius et al., 2020) sehingga dapat mempengaruhi keinginannya pembayaran tax amnsety berpengaruh terhadap pada kepatuhan perpajakan. Semakin banyak WP pajak yang setuju pada Tax Amnesty menunjukkan tingkat kepatuhan perpajakan awalnya rendah. Kemauan WP secara sukarela untuk mengikuti program pengampunan pajak menunjukkan sikap yang positif sehingga dapat meningkatkan kepatuhan WP saat ini (Ajzen, 1991), (Inasius et al., 2020), (Kartini, 2018). Hasil jawaban responden terbanyak 66 persen setuju dan 33 persen sangat setuju pada instrumen no 1 yang menjelaskan WP secara sukarela menyampaikan surat pernyataan harta untuk mendapatkan pengampunan pajak karena sebelumnya tidak menyantumkkan harta tersebut pada laporan SPT nya. Hasil ini menunjukkan hampir 99 persen responden sebelumnya tidak patuh dalam sistem perpajakannya dengan berbagai alasan tertentu. Sikap seseorang dalam membayarkan pajak dapat dipengaruhi oleh faktor internal maupun eksternal. Dengan adanya program tax Amnsety dapat meningkatkan kepatuhan WP terhadap sistem perpajakan. 


\section{SIMPULAN}

Berdasarkan hasil analisis dan pembahasan yang telah, maka dapat ditarik simpulan bahwa semakin tinggi persepsi penggelapan pajak maka semakin besar ketidakpatuhan perpajakannya. Persepsi keadilan sistem perpajakan tidak berpengaruh signifikan terhadap kepatuhan perpajakan karena kepatuhan WP lebih karena kemungkinan mendapatkan sanksi perpajakan bila tidak patuh. Hasil penelitian juga menjelaskan bahwa banyak wajib pajak setuju dengan program pengampunan pajak (Tax Amnesty). Penelitian ini membuktikan bahwa semakin besar wajib pajak melakukan Tax Amnesty maka semakin kecil tingkat kepatuhan awal pada sistem perpajakan. Hasil ini menunjukkan wajib pajak cenderung kurang patuh melaporkan aset yang dimiliki sehingga saat adanya program Tax Amnesty mereka berusaha memanfaatkan untuk mendapat pengampunan pajak.

Berdasarkan simpulan penelitian maka saran yakni penelitian ini dapat dikembangkan pada objek penelitian yang berbeda dan lokasi yang berbeda untuk dapat mengeneralisasi hasil penelitian. Penelitian ini dapat dilanjutkan dengan menguji persepsi-persepsi lain yang mempengaruhi kepatuhan wajib pajak.

\section{REFERENSI}

Ajzen, I. (1991). The Theory of Planned Behavior. Organizational Behavior and Human Decision Processes, 50, 179-211.

Andarini, P. (2010). Dampak dimensi keadilan pajak terhadap tingkat kepatuhan wajib pajak badan. Skripsi (Semarang: UniversitasDiponegoro), 1-97.

Balipost. (2019, March). Cuma Segini, Persentase Kontribusi WP OP di Bali.

Basri, Yesi M. Surya, Raja. Fitriasari, Resy. Novriyan, Rahmat. Tania, T. S. (2014). Studi ketidakpatuhan pajak: faktor yang mempengaruhinya (kasus pada wajib pajak orang pribadi yang terdaftar di kpp pratama tampan pekanbaru). Http:/ / Repository.Unri.Ac.Id/Xmlui/Handle/123456789/6491.

Berutu, D. A., \& Harto, P. (2013). Persepsi Keadilan Pajak Terhadap Perilaku Kepatuhan Wajib Pajak Orang Pribadi (Wpop). Diponegoro Journal of Accounting, 0(0), 265-274.

Cahyonowati, N. (2011). Model Moral Dan Kepatuhan Perpajakan. JAAI, 15(2), 161-177.

Chau, G., \& Leung, P. (2009). A critical review of Fischer tax compliance model: A research synthesis. Journal of Accounting and Taxation, 1(2), 034-040,

Chin, W. W., \& Todd, P. A. (1995). On the use, usefulness, and ease of use of structural equation modeling in mis research: A note of caution. MIS Quarterly: Management Information Systems, 19(2), 237-246. https: / / doi.org/10,2307/249690

Dhanayanti, Meli; Suardana, A. (2017). Pengaruh Persepsi Wajib Pajak Mengenai Penggelapan Pajak Dan Keadilan Sistem Perpajakan Pada Kepatuhan Pajak. E-Jurnal Akuntansi, 20(2), 1504-1533. https:/ / doi.org/10,24843/EJA.2017.v20,102.p23

Doran, M. (2009). Scholarship @ georgetown law scholarship @ georgetown law 2009 tax penalties and tax compliance tax penalties and tax compliance article tax penalties and tax compliance. Harvard Journal on Legislation, 161, 111-161. 
https:/ / scholarship.law.georgetown.edu/facpub/915http:/ /ssrn.com/ht tps:/ / scholarship.law.georgetown.edu/ facpub

Inasius, F., Darijanto, G., Gani, E., \& Soepriyanto, G. (2020). Tax Compliance After the Implementation of Tax Amnesty in Indonesia. SAGE Open, 10(4). https:/ / doi.org/10,1177/2158244020968793

Kartini, U. (2018). Pengaruh Tax Amnesty dan Sanksi Perpajakan terhadap Pepatuhan Wajib Pajak Orang Pribadi di Kantor Pelayanan Pajak Pratama Kabupeten Purworejo pada Tahun 2016. Universitas Negeri Yogyakarta.

Kemenkeu. (2019). APBN Kita 2019. In Kemenkeu.Go.Id (Issue April). https:/ / www.kemenkeu.go.id/media/14243/apbn-kita-januari-2020,pdf

Lederman, L. (2003). Digital Repository @ Maurer Law The Interplay Between Norms and Enforcement in Tax Compliance Volume 64, Number 6, 2003 The Interplay Between Norms and Enforcement in Tax Compliance. Ohio State Law Journal, 64(6), 1454-1514.

McGee, R. W., Ho, S. S. M., \& Li, A. Y. S. (2006). A ComparativeStudy on Perceived Ethics of Tax Evasion: Hong Kong vs. the United States. Word Business Ethics Forum, Hong Kong and Macau, 1-25. https:/ / doi.org/10,2139/ssrn.930533

Otekunrin, A. O., Nwanji, T. I., Eluyela, D. F., Inegbedion, H., \& Eleda, T. (2021). E-tax system effectiveness in reducing tax evasion in Nigeria. Problems and Perspectives in Management, 19(4), 175-185. https:/ / doi.org/10,21511/ppm.19(4).2021.15

Picur, R. D., \& Riahi-Belkaoui, A. (2006). The impact of bureaucracy, corruption and tax compliance. Review of Accounting and Finance, 5(2), 174-180, https:/ / doi.org/10,1108/14757700610668985

Retyowati, F. D. (2016). Analisis Faktor-faktor yang Mempengaruhi Ketidakpatuhan Wajib Pajak yang Terdaftar di KPP Pratama Sukoharjo. In Skripsi.

Riyanto, Wujarso, Saprudin, R. D. N. (2020). Pengaruh Pengetahuan Perpajakan dan Sanksi Pajak Terhadap Kepatuhan Wajib Pajak UMKM Di Jakarta. Jurnal STEI Ekonomi, 29(02), 44-56. http:/ / eprints.kwikkiangie.ac.id/id/eprint/1036

Surahman, W., \& Putra, U. Y. (2018). Faktor-Faktor Persepsi Wajib Pajak Terhadap Etika Penggelapan Pajak. Jurnal REKSA: Rekayasa Keuangan, Syariah Dan Audit, 5(1), 1. https://doi.org/10,12928/j.reksa.v5i1.140

Surono, S., \& Hidayat, N. (2014). Faktor Penggelapan Pajak, Interaksi Fiskus dengan Wajib Pajak dan Kepatuhan Pajak di Kantor Pelayanan Pajak Pratama Bogor. Jurnal Riset Akuntansi E Perpajakan (JRAP), 1(02), 136-148. https:/ / doi.org/10,35838/jrap.v1i02.72

Susmiantu., \& Kusmuriyanto. (2014). Pengaruh Pengetahuan Perpajakan, Ketegasan Sanksi Perpajakan Dan Keadilan Perpajakan Terhadap Kepatuhan Wajib Pajak Umkm Di Kota Semarang. Accounting Analysis Journal, 3(3), 378-386. https:/ /doi.org/10,15294/aaj.v3i3.4220

Suwikyo, Edi. 2019. Hingga Juli 2019, Kepatuhan Wajib Pajak Baru 67,2 Persen. Bisnis.com. https: / / ekonomi.bisnis.com/read/20190807/259/1133668/hingga-juli2019-kepatuhan-wajib-pajak-baru-672-persen 